\title{
ESIF Policies and Their Impact on The Development of EU Members: A Review and Research Agenda
}

\section{Adriana Z. F. C. NISHIMURA ${ }^{1 *}$, Manuel AU-YONG-OLIVEIRA², Maria José SOUSA ${ }^{3}$}

${ }^{1}$ Ph.D. Student, University of Aveiro, Department of Economics, Management, Industrial Engineering, and Tourism. GOVCOPP, Aveiro, Portugal; E-mail: adriana.nishimura@ua.pt

${ }^{2}$ Professor, Ph.D., INESC TEC, University of Aveiro, Department of Economics, Management, Industrial Engineering, and Tourism. GOVCOPP, Aveiro, Portugal; E-mail mao@ua.pt

${ }^{3}$ Professor, Ph.D., Business Research Unit (BRU-Iscte), University Institute of Lisbon (ISCTE-IUL), Lisbon, Portugal;

E-mail: maria.jose.sousa@iscte-iul.pt

${ }^{*}$ Corresponding Author

\author{
Received: 04.06.2021 Accepted: 15.08.2021 Published: 19.10.2021 DOI: 10.47750/QAS/22.184.06
}

\begin{abstract}
The European Structural and Investment Funds (ESIF) represent the main instrument of European Cohesion Policy to sustain territorial development and to eliminate regional disparities between the EU member states. The study of the impacts of ESIF on the economic growth and development of EU members has gained increasing attention in the academic community, and there has been significant scientific production on this topic. This study consists of a bibliometric analysis of articles published in the period from 2011 to 2020 and indexed in two of the main scientific databases: Web of Science (WoS) and Scopus. The results of the bibliometric analysis point to relevant trends on the subject, such as the growing number of publications over the years; the great concentration of studies applied in Central and Eastern European (CEE) countries, namely Romania; and the current interest of researchers in important topics associated with European funds, such as the competitiveness and innovation of SMEs, climate change, economic impact of global crises, sustainable development, institutional capacity of organisations, and cross-border cooperation.
\end{abstract}

Keywords: ESIF Policy Analysis, Bibliometric Study, European Funds, European Development, Research Agenda

\section{Introduction}

The European Structural and Investment Funds (ESIF) are the main instrument of the European Union (EU) investment policy to support economic growth and develop the convergence of EU Member States (MS), fostering competitiveness and promoting the reduction of territorial disparities. For many EU members, funds represent the largest source of financial investment (European Commission, 2017), accounting for up to $70 \%$ of total investment.

In the last decade, studies on the programming, management, absorption and effectiveness of European funds have gained increasing interest from the international scientific community, mostly from the European Union, mainly due to the impacts of the global economic crisis (from 2008 to 2012) on the sustainable growth of member states. In the current pandemic context in which we find ourselves, responsible for an unprecedented economic and social crisis and the deepest global economic recession since the 1930s (OECD, 2020), the EU funding should gain even more prominence in society, since in addition to the multi-annual programming of ESIF, whose next period runs from 2021 to 2027, with expected resources of 1.07 trillion euros, a substantial amount of resources will be disbursed into the fund for the economic recovery of EU members, an additional amount of 750 billion euros, known as the "bazooka" (Dedola et al., 2020).
The European Commission (EC), in conjunction with the MS, has established a multiannual financial framework for the implementation of the European Structural and Investment Funds (ESIF), which were set up to promote the development and socio-economic cohesion of EU members, in an integrated, sustainable and harmonious manner (EUR-Lex, 1957). The five main European funds are: European Regional Development Fund (ERDF); European Social Fund (ESF); Cohesion Fund (FC); European Agricultural Fund for Rural Development (EAFRD); and the European Maritime Affairs and Fisheries Fund (EMFF).

The studies that assess the effectiveness of European funds in achieving their objectives are mostly represented by econometric analyses, and use indicators such as GDP Per Capita, Employment, Gross Value Added, among others. Apparently, there is no consensus among the authors on the effectiveness of the funds. Several studies have found positive effects on the economic growth of MS (Oliveira and Leitão, 2020; Becker et al. 2018; Gagliardi and Percoco, 2017; Maynou et al., 2014; Crescenzi and Giua, 2014; Fiaschi et al., 2011; Checherita et al., 2009; Bähr, 2008; Puigcerver-Peñalver, 2007; Ederveen et al., 2006; Beugelsdijk and Eijffinger, 2005; Dall'erba, 2005; Rodriguez-Pose and Fratesi, 2004; Cappelen et al., 2003; De la Fuente and Vives, 1995). However, some of these studies refer to a few conditionalities, such as:

- the application of funds achieves a more significant effect in regions whose GDP per capita is below $75 \%$ of the EU 
average (Fiaschi et al., 2011);

- there is a higher efficiency of funds in rural areas close to urban centres (Gagliardi and Percoco, 2017);

- funds produce immediate effects on the increase in per capita income, but these do not last beyond the programming period (Becker et al.,2018);

- incentives for education and human capital have a positive medium-term effect (Oliveira and Leitão, 2020). Malakhova et al. (2020) state that there is an economic gap between less developed and developed EU members.

Nevertheless, other studies (Mohl and Hagen, 2010; Dall'erba et al., 2009; Mohl and Hagen, 2008; Dall'erba and Le Gallo, 2008; Esposti and Bussoletti, 2008; Ederveen et al., 2003; Garcia-Milá and McGuire, 2001; Boldrin and Canova, 2001; Sala-i-Martin, 1996) have found practically no significant effects of the funds on the economic growth of EU members, or even negative effects in the long run.

The EU budget for the programming period of 2014-2020 was approximately of 640 billion euros. Figure 1 exhibits the distribution of total budget by MS, according to the typology of the funds. In addition to the main five funds (ERDF, ESF, CF, EAFRD and EMFF), it includes the Youth Employment Initiative
(YEI), which was topped up in 2017 for regions with youth unemployment higher than 25\% in 2016 (EU Data, 2021).

Due to the relevance that this topic has gained, it is important to know the scientific production on the impact of ESIF for the economic growth and development of the EU members in the last decade (from 2011 to 2020).

The data collection for this study is based on Bibliometric Analysis, a quantitative and statistical technique that allows measuring indices of knowledge production and dissemination, tracking the development of multiple scientific areas and the patterns of authorship, publication and use of research results (Costa et al. 2012; Okubo, 1997; Araújo, 2006). The contributions and novelty of this work can be attributed to the fact that no other bibliometric study was found that specifically used the search terms adopted in this data collection.

The remainder of this paper is structured as follows. The second section describes the research methods for this bibliometric analysis. The fourth section describes and discusses the empirical results. Finally, the fifth section presents our final conclusions, limitations of the study and prospects for future research.

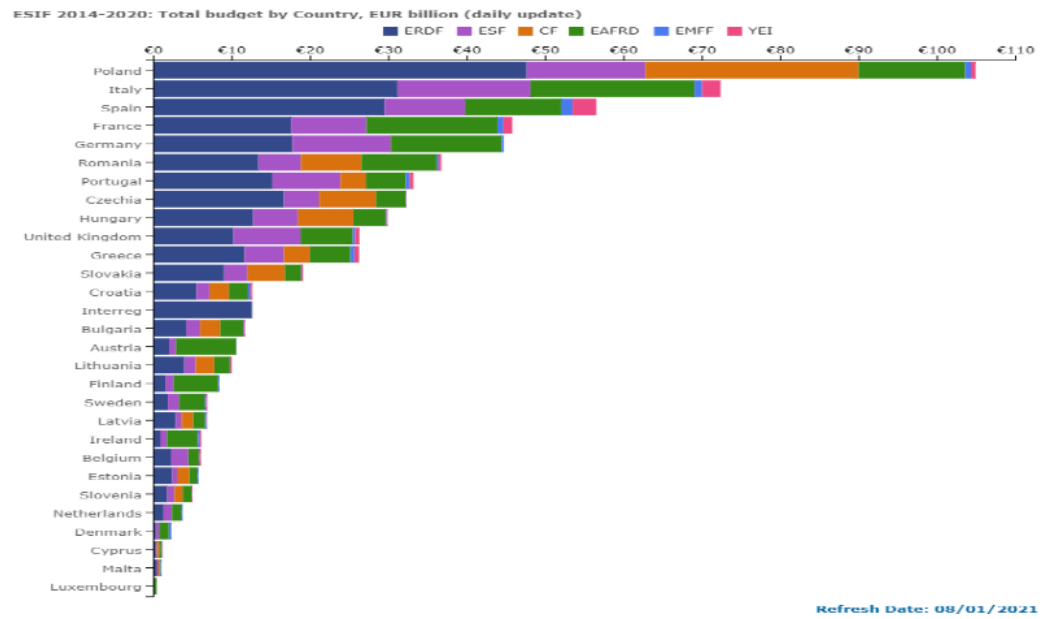

Figure 1: Total ESIF budget by country (EC data, 2021)

\section{Methodological Approach}

\subsection{Bibliometric Analysis}

This research is based on a bibliometric analysis, which is a quantitative and statistical technique that allows the measurement of knowledge production and dissemination indexes, monitoring the development of several scientific areas and the standards of authorship, publication and the use of research results (Costa et al. 2012; Araújo, 2006; Okubo, 1997).

Previously referred to as Statistical Bibliography, the term Bibliometrics was consolidated by Pritchard (1969), with the publication of the article "Statistical Bibliography or Bibliometrics?". The Information Science known as Bibliometrics is performed by different metrics, which measure scientific production and its importance, either in terms of an author, an institution, a country, through its productivity (article count), to an article through its relevance, influence on other researchers (number of citations), or to a journal through the relevance of the articles published (impact factor) in recent years (University of Lisbon, 2021).

According to Župič and Čater (2015), synthesizing past research findings is one of the most important tasks for advancing a particular line of research; and bibliometric methods provide a useful aid in literature reviews even before the reading begins, guiding the researcher to the most influential works and mapping the field of research free of subjective bias, common in literature reviews.

\subsection{Data Collection}

Data collection was carried out on two of the most relevant scientific databases: Clarivate Analytics' Web of Science (WoS) and Elsevier's Scopus, during the period from 12 to 20 October 2020.

\subsection{Search Criteria}

The search criteria adopted was guided to map the scientific production related to the object of the study: the European structural and investment funds (ESIF), and their relationship with the development and economic growth of the EU members. The search expressions with Boolean operators were limited to the terms (Chart 1): 


\section{GENERAL MANAGEMENT}

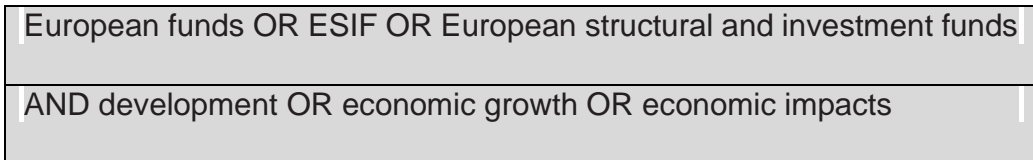

Chart 1: Search expressions

We searched for documents that contained these terms in the title, abstract or keywords, and limited the search to articles published in journals, in the last ten years (2011-2020). All areas of knowledge were considered in the search. The reason for limiting the type of documents to articles is that their publication processing is more accredited, as they are based on recognized evaluation criteria, such as blind peer-review (scientific arbitration).

The search resulted in three different samples of documents: articles from Scopus $(n=124)$, articles from Web of Science $(n$ $=104$ ) and the sum of all articles from the two databases, excluding duplicates $(n=170)$, as 58 articles are common to the Scopus and WoS databases.

\subsection{Bibliometric Analysis Categories}

The bibliometric analysis categories of this study were selected from the main indicators available in the Scopus and Web of Science databases and take into account the categories consolidated in the literature on bibliometric analysis. Thus, the categories of bibliometric analysis for this study are the following:

$$
\begin{aligned}
& \text { 1. Year of publication } \\
& \text { 2. Authorship }
\end{aligned}
$$

When comparing the distribution of articles published in the Web of Science $(n=104)$ and Scopus $(n=124)$ databases over the years under analysis (Graph 1), we can observe in WoS a generally increasing trend until 2017, when it reaches the maximum number of publications (24), followed by a drop in 2019 , and a rise in 2020 . $90 \%$ of WoS publications are

$\begin{array}{ll}3 . & \text { Source (journals) } \\ 4 . & \text { Country } \\ 5 . & \text { Affiliation } \\ 6 . & \text { Subject area } \\ \text { 7. } & \text { Funding sponsorship } \\ \text { 8. } & \text { Language } \\ 9 . & \text { Open access } \\ 10 . & \text { Factor impacts } \\ 11 . & \text { Keywords } \\ 12 . & \text { Research agenda and trends }\end{array}$

\subsection{Statistical Data Analysis}

The data mined from the two databases were exported to Microsoft Excel, and statistical analyses were applied, for each of the categories listed in the previous subsection.

\section{Results and Discussion}

The results of this study will be presented and discussed by the categories defined for the bibliometric analysis, as shown in the former section.

\subsection{Year of publication}

concentrated in the period from 2016 to 2020. In turn, publications in Scopus were more distributed over the years, reaching their peak in 2019 (22), and followed by a steep drop in 2020, when it returned to the initial number of articles of 2011 (8). The average number of articles published per year in Scopus was 12.4, and in WoS, 10.4 .

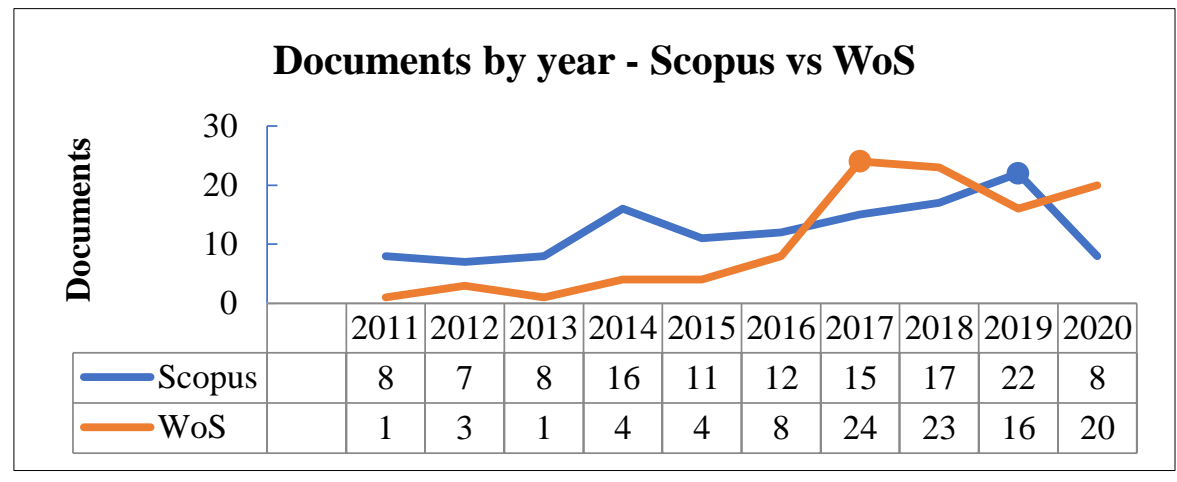

Graph 1: Documents by year- Scopus vs WoS

Graph 2 shows the sample distribution of the total nonduplicated articles from the WoS and Scopus databases $(n=$ 170 ), where we can observe a higher concentration of articles published in the years 2017 and 2018 (28 in both years), and a decreasing trend since then. For this sample, an average of 17,0 articles were published per year. 


\section{GENERAL MANAGEMENT}

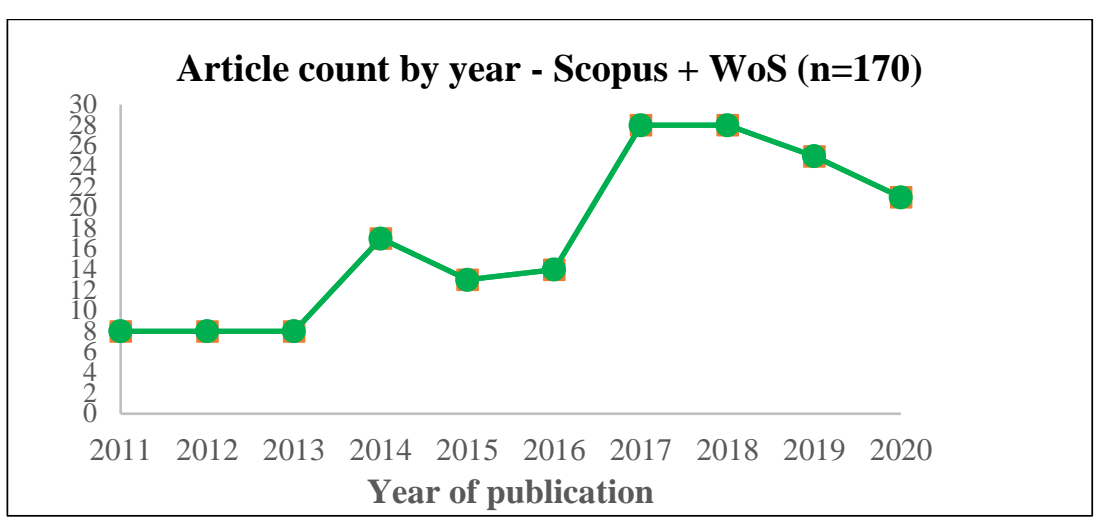

Graph 2: Documents by year- Scopus + WoS

\subsection{Authorship}

The articles found in Scopus database were written by 254 different authors, and the authors with the largest number of documents are Bostan, I., Hapenciuc, C.V., Morosan, A.A. and Stanciu, P., with 3 articles each. In the WoS database, articles

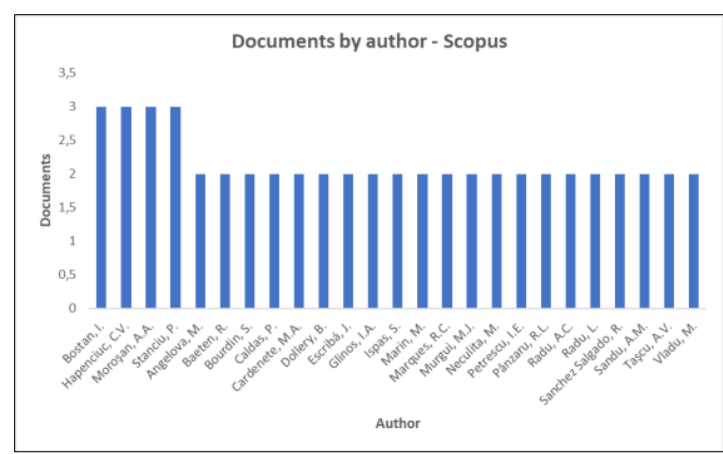

Graph 3: Documents by author - Scopus

\subsection{Source (journals)}

As for the source of the documents, the articles from the Scopus database sample $(n=124)$ were published in 78 different journals. The journal with the highest number of articles is Quality - Access to Success, with 26 documents, which corresponds to $20.9 \%$ of the sample. In turn, the articles from the WoS database sample were published in 69 different journals, and the most represented is the Scientific PapersSeries Management Economic Engineering in Agriculture and Rural Development, with 14 documents (13.5\% of the sample), were written by a similar number of authors (258), and the authors with the highest number of articles are Neculita, M., with 5 articles, followed by Vladu, M., Cretu, D., with 4 articles each; and Mogodan, A., with 3 articles. These authors are all from Romania. Graphs 3 and 4 present the authors who wrote at least 2 articles, as the main author or co-author, and refer to the Scopus and WoS Databases, respectively.

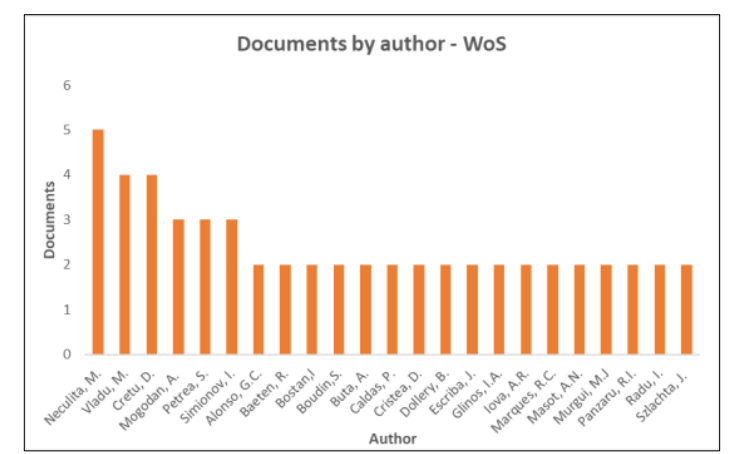

Graph 4: Documents by author - WoS

followed by Quality - Access to Success, with 5 documents (4.8\% of the sample). Graphs 5 and 6 demonstrate journals that had more than 2 documents published in the Scopus and WoS databases, respectively.

The Quality - Access to Success Journal, from Romania, presents an $\mathrm{H}$ Index 20, and a Q3 in the Business, Management and Accounting area, in the Scimago Journal \& Country Rank (SJR). The Scientific Papers-Series Management Economic Engineering in Agriculture and Rural Development is not indexed in the Scopus database, the reason why it is not ranked by SJR.

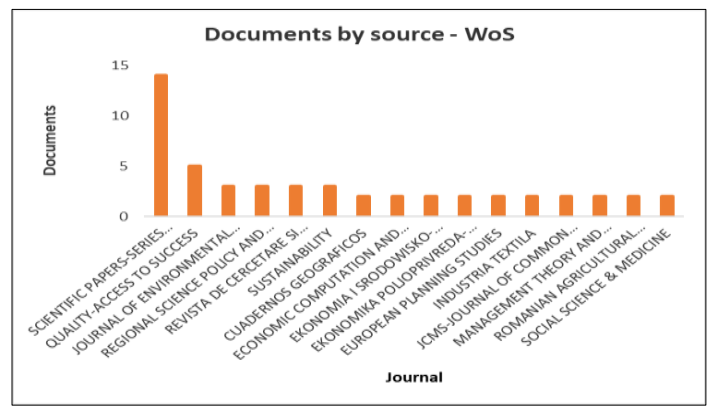

Graph 6: Documents by source - WoS 


\section{GENERAL MANAGEMENT}

In the sample of non-duplicated articles from the WoS and Scopus databases $(n=170)$, the articles were published in 105 different journals. Graph 7 shows journals that have had more than 3 publications in the period of analysis. The first position is for Quality - Access to Success Journal, with 26 documents, followed by Scientific Papers-Series Management Economic Engineering in Agriculture and Rural Development, with 14 documents.

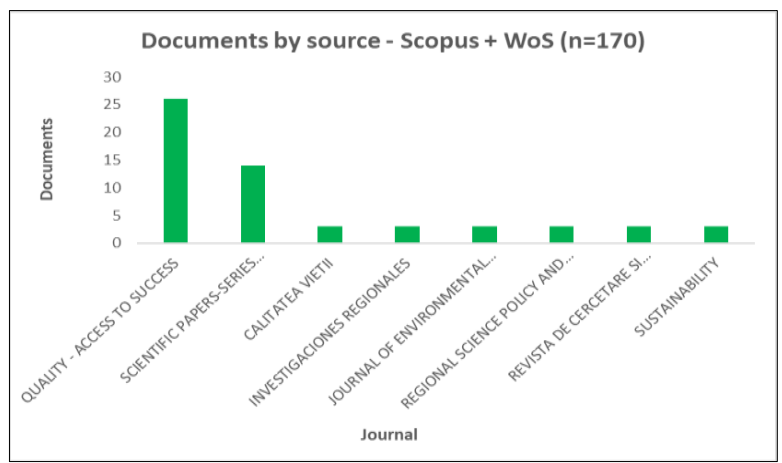

Graph 7: Documents by source - Scopus + WoS

\subsection{Country}

The articles found in the Scopus Database are from 24 different countries, represented in 135 documents (taking into account the co-authorships). The country that published the most is Romania, with 55 documents $(40.7 \%$ of the sample), followed by Spain, with 13 documents $(9.6 \%)$, Poland, with 11 documents $(8.1 \%)$, the Netherlands, with 8 documents $(5.9 \%)$, Italy and Portugal, with 7 documents each (5.2\%) and Belgium, with

$$
5 \text { documents }
$$
$(3.7 \%)$. from 24 different countries, but six of them differ between the two databases: Croatia, Latvia, Oman, Serbia, Ukraine and Greece, with one document each. The country that published the most is also Romania, with 41 documents, corresponding to $32.8 \%$ of the sample, followed by Poland, with 14 documents $(11.2 \%)$, Spain, with 13 documents (10.4\%), Portugal, with 7 documents $(5.6 \%)$, the Netherlands, Italy and the United Kingdom with 6 documents each (4.8\%), and Belgium, with 5 documents (4.0\%). Graphs 8 and 9 show the document count by country in the Scopus and WoS databases, respectively.

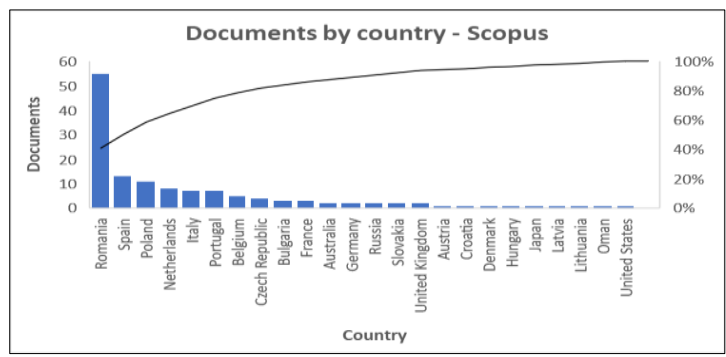

Graph 8: Documents by country - Scopus

If we consider the spatial distribution of where the studies were empirically applied (which does not always correspond to the location of the authors' home institution), the sample of 170 non-duplicate articles does not have a normal distribution across the $28 \mathrm{EU}$ members (before the UK left the EU), as

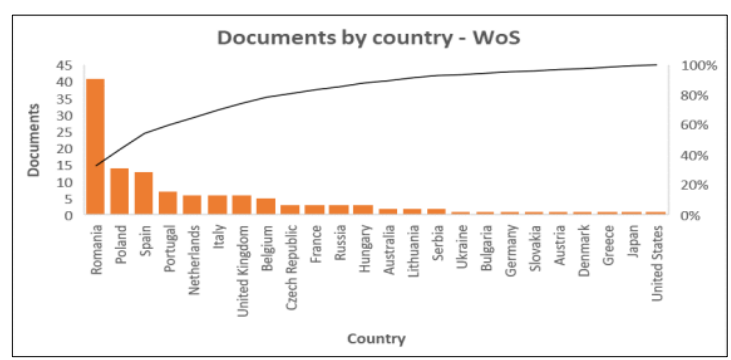

Graph 9: Documents by country - WoS

shown in Graph10. For this sample, the MS that presented the highest application of the studies were Romania, with 74 articles, followed by Poland (21 articles), Spain (20), Italy (10), and Portugal (8).

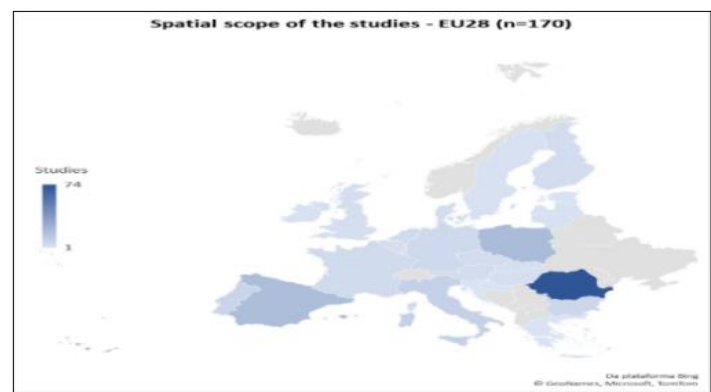

Graph 10: Spatial distribution of the studies (Scopus + WoS) 


\section{GENERAL MANAGEMENT}

Additionally, if we consider the empirical application of nonduplicated studies $(n=170)$ by European regions where they were applied (graph 11), we have a predominance of Central and Eastern Europe (CEE), with $66 \%$ of the studies, followed by Southern Europe (18\% of the studies), and EU cross-border studies (12\%).

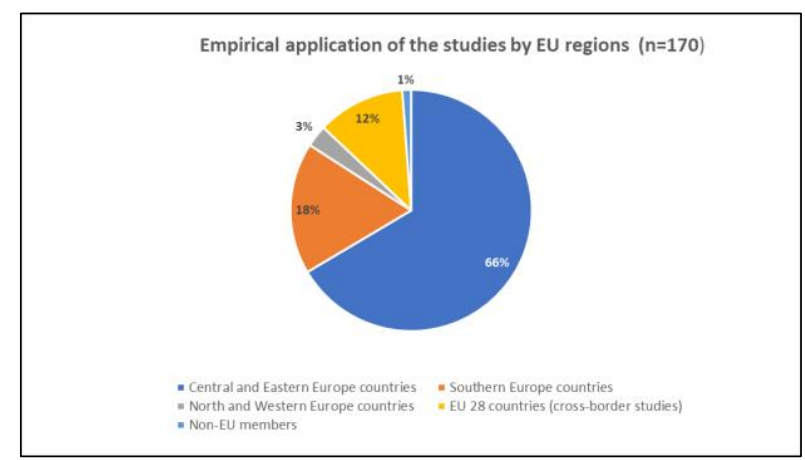

Graph 11: Empirical application of the studies (Scopus + WoS)

\subsection{Affiliation}

In the Scopus database articles are from 127 different institutions of affiliation. The most representative institution is Bucharest University of Economic Studies, which published 22 documents, corresponding to $17.7 \%$ of the articles, followed by Universitate a Stefan cel Mare din Suceavac, with 7 documents (5.6\%) and Academia Româna, with 4 documents (3.2\%). All of them are Romanian. As for the WoS database, articles are from

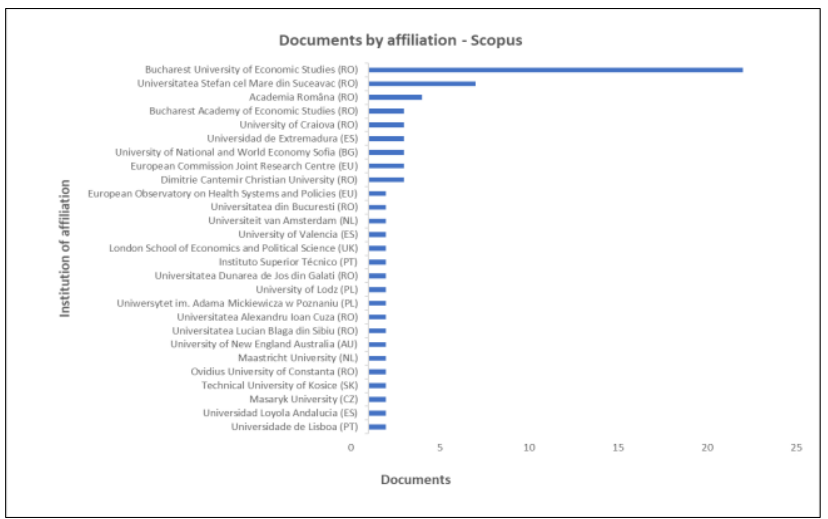

Graph 12: Documents by affiliation - Scopus

\subsection{Subject Area}

The Scopus database refers to 18 different subject areas for classifying the selected articles, as shown in graph 14 . The area that presents the greatest representativeness is Social Sciences, with 60 articles classified (48.4\% of total documents), followed by Business, Management and Accounting, with 44
121 different institutions. The institutions that have published the most are also from Romania. The first one is Bucharest University of Economic Studies, with 14 documents (13.5\% of all documents), followed by the University of Agronomic Science Veterinary Medicine Bucharest, with 9 documents (8.7\%), Dunarea de Jos University Galati, with 5 documents (4.8\%) and University of Craiova, with 4 documents (3.8\%). Graphs 12 and 13 exhibit institutions that had more than 2 documents published in the Scopus and WoS databases, respectively.

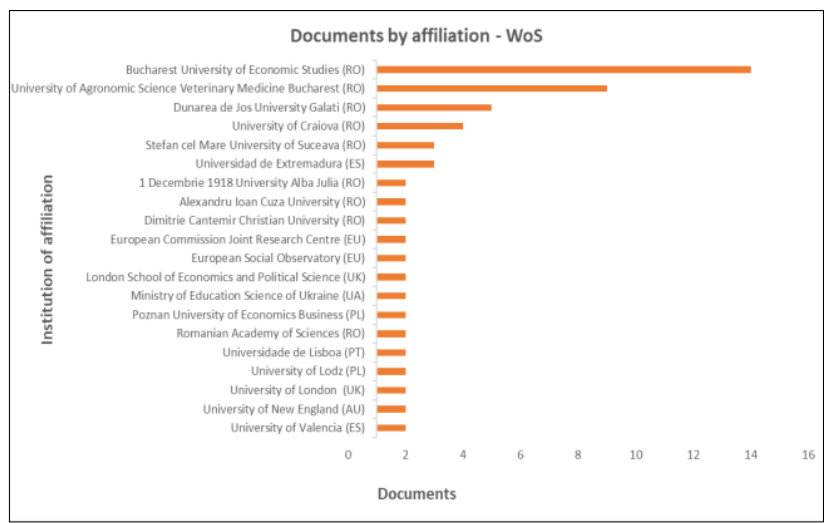

Graph 13: Documents by affiliation - WoS

articles (35.5\%), Economics, Econometrics and Finance, with 27 articles (21.8\%); and Environmental Science, with 23 articles $(18.5 \%)$. For the WoS database (graph 15), the articles were classified in 25 different areas. The most prominent areas are Business Economics (31 articles, representing 29.8\% of total documents), followed by Agriculture (19 articles, 18.3\%), Environmental Sciences Ecology (14 articles, 13.5\%); and Geography (12 articles, 11.5\%). 


\section{GENERAL MANAGEMENT}

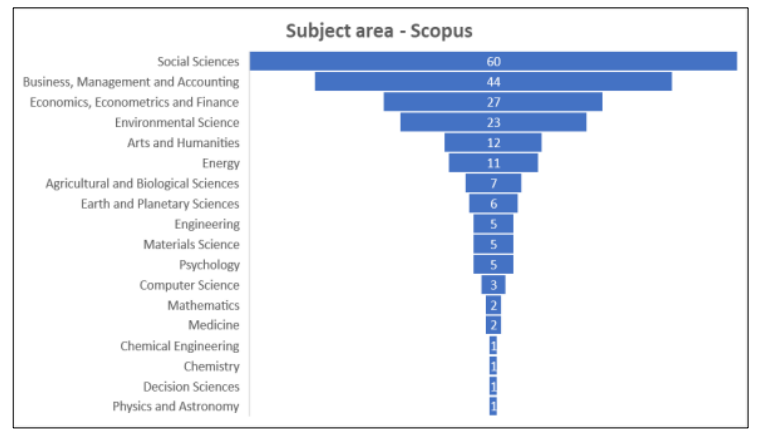

Graph 14: Subject area - Scopus

\subsection{Funding sponsorship}

Regarding the sponsorship of the publications, in the Scopus Database (graph 16) there are 21 different sponsors,

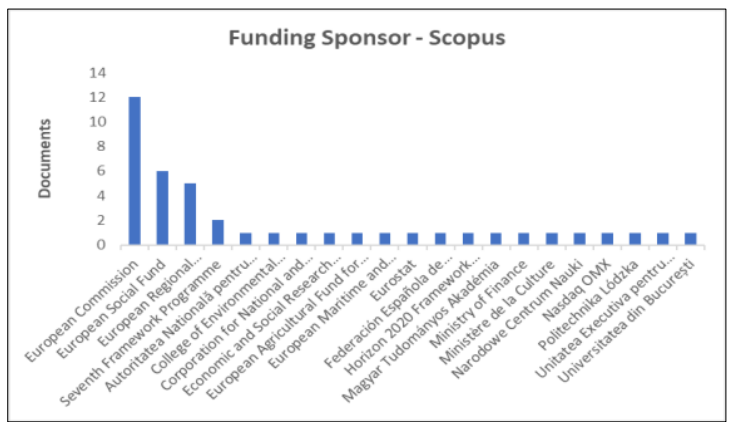

Graph 16: Funding sponsor - Scopus

\subsection{Language}

As shown in Graph 18, most of the documents analysed

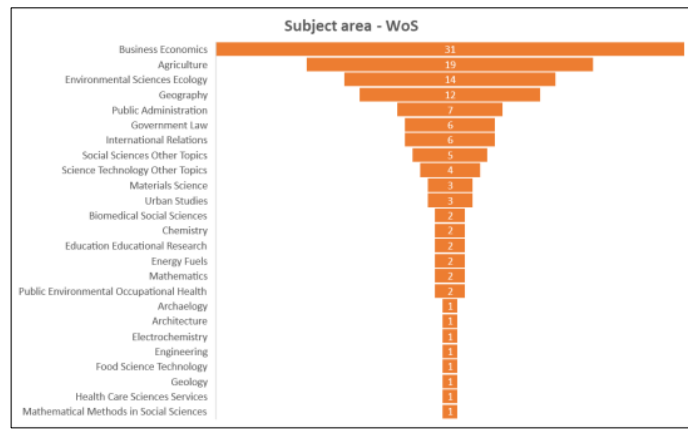

Graph 15: Subject area - WoS

individually or in cooperation, that financed a total of 28 articles, corresponding to $22.6 \%$ of the sample. In the WoS database (graph 17) there are 25 different sponsors that financed 24 papers $(23.1 \%)$

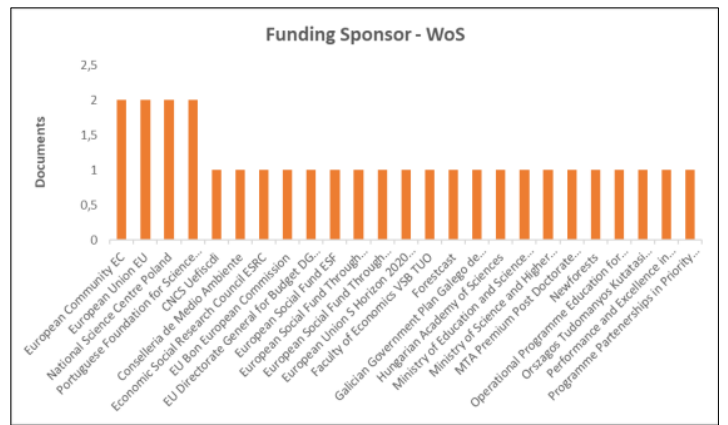

Graph 17: Funding sponsor - WoS

were written in English (84.7\% of the Scopus articles and $83.7 \%$ of the Web of Science articles), followed by Spanish $(4.0 \%$ of the Scopus articles and $7.7 \%$ of the WoS articles) and Romanian (4.8\% of the Scopus articles).

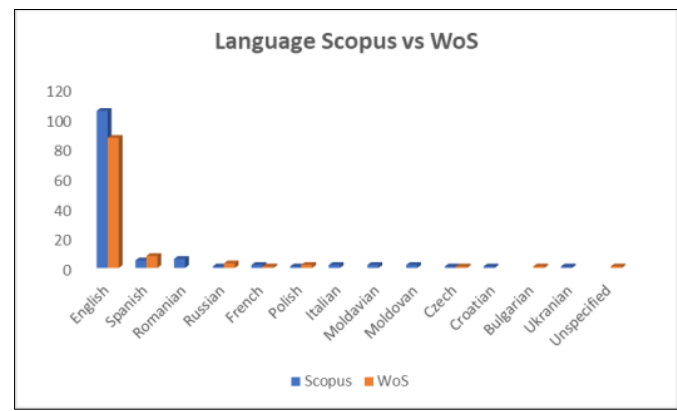

Graph 18: Language - Scopus vs WoS

\subsection{Open access}

Open Access types available in Scopus, besides all open access, are gold open (documents that are in journals which only publish open access); hybrid gold (documents that are in journals which provide authors with the choice of publishing open access); bronze (published version of record or manuscript accepted for publication. The publisher has chosen to provide temporary or permanent free access); and green (published version or manuscript accepted for publication, available at a repository). As shown in graphs 19 and 20, Scopus performs a good percentage of open access. $86 \%$ of Scopus articles $(n=124)$ are open access. 


\section{GENERAL MANAGEMENT}

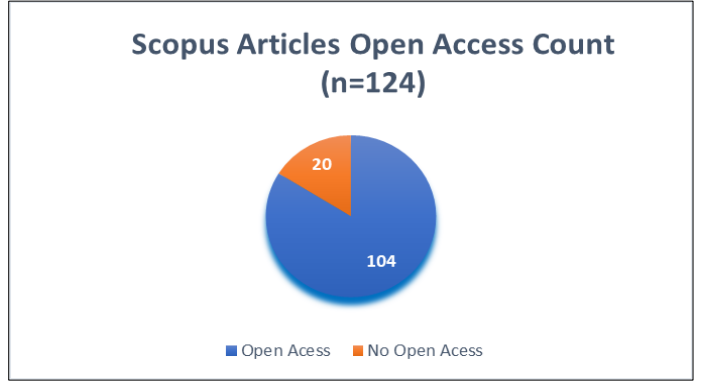

Graph 19: Scopus open access count

In the Web of Science (graphs 21 and 22), open access types are slightly different. The open access status can be one of the following: gold DOAJ (articles published in journals listed on the Directory of Open Access Journals (DOAJ), for which the journals must have a license in accordance with the Budapest Open Access Initiative); gold other (open access articles not

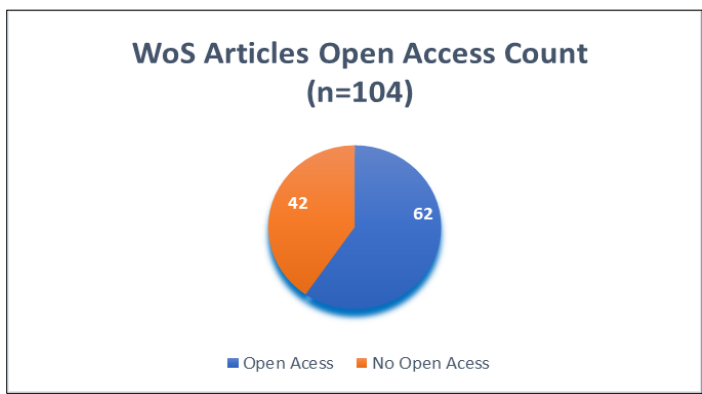

Graph 21: WoS open access count

\subsection{Factor impact}

\section{Times Cited}

Times Cited is one of the most important metrics of factor impact. It represents the number of citations for a scientific publication. In the sample of articles from the Scopus database $(n=124)$, the sum of all citations, which occurred in the period from 2011 to 2020 , added up to 417 . The average number of citations per article was 3.4, in an interval from of 0 to 98 citations. 56 articles were never cited (45.2\% of the sample), 23
Scopus Articles Open Access Types Count $(n=104)$

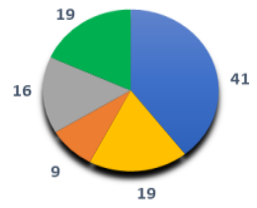

All open access Gold Hybrid Gold a Bronze Green

Graph 20: Scopus open access count by types

listed on the DOAJ, most of them are hybrid journals); bronze (free access to an article for a limited time); green published and green accepted (final published or accepted manuscripts). WoS open access status is not as extensive as Scopus (59.6\% of the 104 WoS articles were open access, about 33\% less than Scopus).

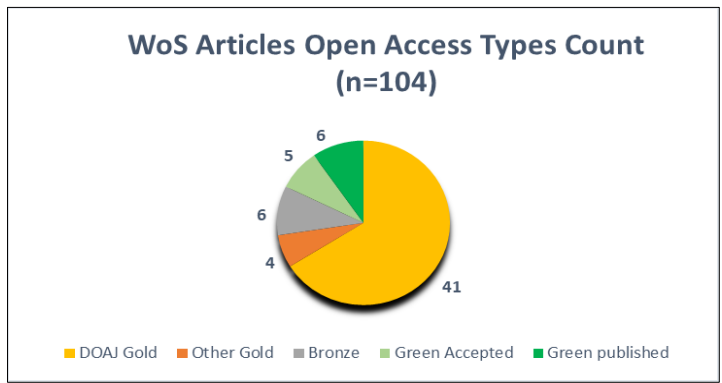

Graph 22: WoS open access count by types

articles were cited once (18.5\%), 13 articles were cited twice $(10.5 \%), 5$ articles were cited three times $(4,0 \%), 2$ articles were cited four times (1.6\%), 8 articles were cited five times $(6.5 \%)$, 3 articles were cited six times (2.4\%), 1 article was cited seven times $(0.8 \%), 2$ articles were cited eight times (1.6\%), 2 articles were cited nine times (1.6\%), 1 article was cited ten times $(0.8 \%), 2$ articles were cited 11 times (1.6\%), 1 article was cited 18 times, 1 article was cited 20 times, 1 article was cited 21 times, 1 article was cited 27 times, 1 article was cited 30 times and 1 article was cited 98 times, each one corresponding to $0.8 \%$ of the sample. Table 1 shows the four most cited articles on the Scopus database.

\begin{tabular}{|l|l|l|l|l|}
\hline Title & Author & Journal & $\begin{array}{l}\text { Year } \\
\text { publication }\end{array}$ & Times Cited \\
\hline $\begin{array}{l}\text { An assessment of the regional } \\
\text { potential for solar power generation in } \\
\text { EU-28 }\end{array}$ & $\begin{array}{l}\text { Castillo, C.P.; Silva, } \\
\text { F.B.; Lavalle, C. }\end{array}$ & Energy Policy & 2016 & 98 \\
\hline $\begin{array}{l}\text { Guest editorial on research and } \\
\text { innovation strategies for smart } \\
\text { specialisation in Europe: theory and } \\
\text { practice of new innovation policy } \\
\text { approaches }\end{array}$ & Landabaso, M. & $\begin{array}{l}\text { European Journal of } \\
\text { Innovation } \\
\text { Management }\end{array}$ & 2014 & 30 \\
\hline $\begin{array}{l}\text { Rebalancing interest } \\
\text { representation? Su } \\
\text { democracy and EU Funding of Civil } \\
\text { Society Organizations }\end{array}$ & & $\begin{array}{l}\text { JCMS-Journal of } \\
\text { Common Market } \\
\text { Studies }\end{array}$ & 2014 & 27 \\
\hline $\begin{array}{l}\text { Cohesion policy after Brexit: the } \\
\text { economic, social and institutional } \\
\text { challenges }\end{array}$ & Bachtler, J.; Begg, I. & $\begin{array}{l}\text { Journal of Social } \\
\text { Policy }\end{array}$ & 2017 & 21 \\
\hline
\end{tabular}

Table 1: Most cited articles in Scopus 


\section{GENERAL MANAGEMENT}

Graph 23 demonstrates the distribution of articles by times cited, on a logarithmic scale, where it is observed that the great majority of articles were cited less than 10 times.

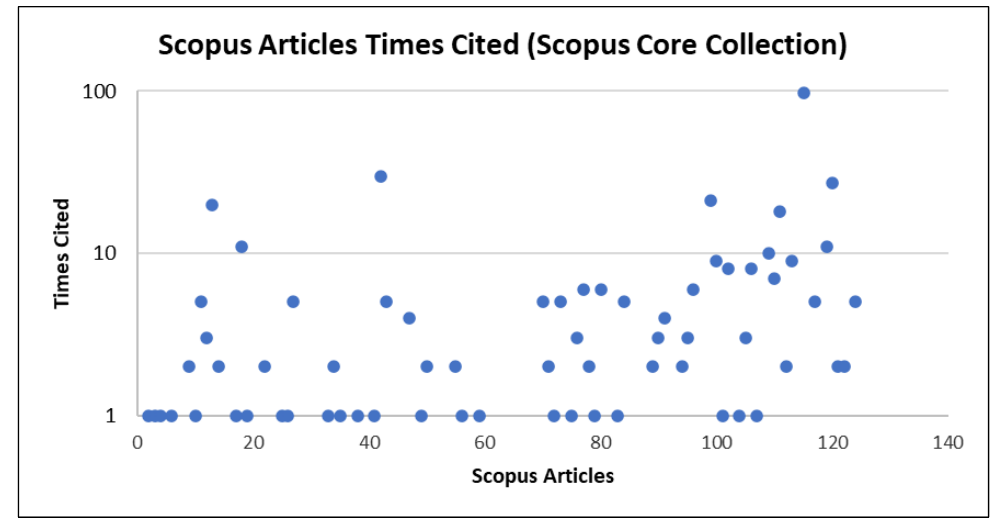

Graph 23: Scopus articles times cited

In turn, articles from the Web of Science database $(n=104)$, led to a total of 292 citations, in the period from 2011 to 2020. The average number of citations per article was 2.8, in an interval from 0 to 79 citations. 50 articles were never cited (48.1\% of the sample), 18 articles were cited once (17.3\%), 8 articles were cited twice (7.7\%), 7 articles were cited thrice $(6.7 \%), 4$ articles were cited four times (3.8\%), 4 articles were cited five times (3.8\%), 1 article was cited six times $1.0 \%), 4$ articles were cited seven times (3.8\%), 2 articles were cited eight times (1.9\%), 2 articles were cited nine times (1.9\%), 1 article was cited 11 times, 1 article was cited 15 times, 1 article was cited 28 times, and 1 article was cited 79 times, each one corresponding to $1.0 \%$ of the sample. Table 2 shows the four most cited articles on the WoS database, three of them are the same as in the Scopus database. Graph 24 demonstrates the distribution of articles by times cited, on a logarithmic scale, where the great majority of articles were cited less than 10 times as well.

\begin{tabular}{|c|c|c|c|c|}
\hline Title & Author & Journal & $\begin{array}{l}\text { Year of } \\
\text { publication }\end{array}$ & $\begin{array}{l}\text { Times } \\
\text { Cited }\end{array}$ \\
\hline $\begin{array}{l}\text { An assessment of the regional potential } \\
\text { for solar power generation in EU-28 }\end{array}$ & $\begin{array}{lr}\text { Castillo, } & \text { C.P.; } \\
\text { Silva, } & \text { F.B.E.; } \\
\text { Lavalle, C. } & \end{array}$ & Energy Policy & 2016 & 78 \\
\hline $\begin{array}{l}\text { Rebalancing EU Interest representation? } \\
\text { Associative democracy and EU Funding } \\
\text { of Civil Society Organizations }\end{array}$ & Salgado, R.S. & $\begin{array}{l}\text { JCMS-Journal of } \\
\text { Common Market } \\
\text { Studies }\end{array}$ & 2014 & 28 \\
\hline $\begin{array}{l}\begin{array}{l}\text { Cohesion policy after } \\
\text { economic, social and } \\
\text { challenges }\end{array} \\
\text { chexit: the } \\
\text { institutional }\end{array}$ & $\begin{array}{l}\text { Bachtler, J.; Begg, } \\
\text { I. }\end{array}$ & $\begin{array}{l}\text { Journal of Social } \\
\text { Policy }\end{array}$ & 2017 & 15 \\
\hline $\begin{array}{l}\text { Using a VGI and GIS-Based multicriteria } \\
\text { approach for assessing the potential of } \\
\text { rural tourism in Extremadura (Spain) }\end{array}$ & $\begin{array}{l}\text { Gonzalez-Ramiro, } \\
\text { A.; Goncalves, G.; } \\
\text { Sanchez-Rios, A.; } \\
\text { Jeong, J.S. }\end{array}$ & Sustainability & 2016 & 11 \\
\hline
\end{tabular}

Table 2: Most cited articles in WoS

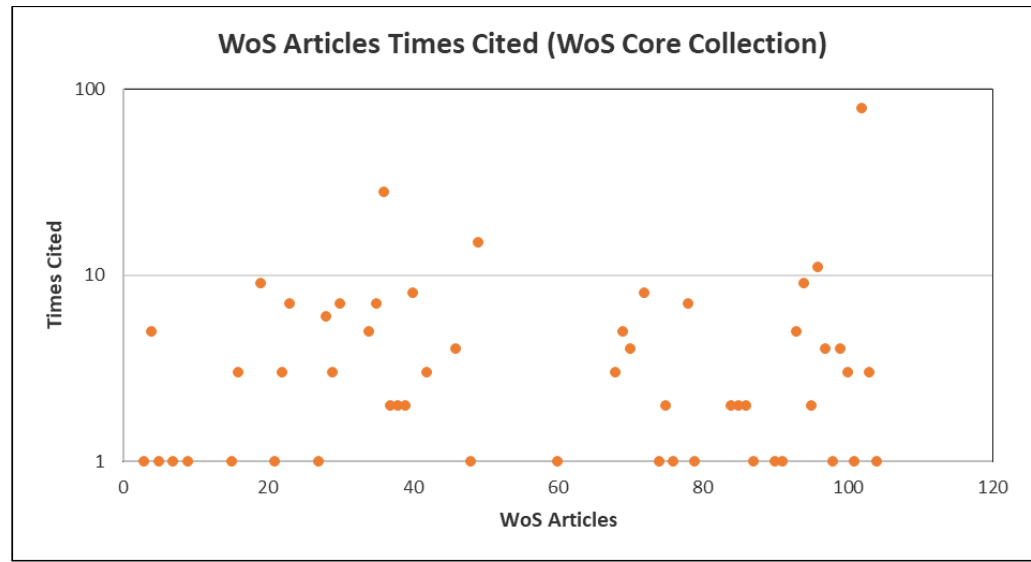

Graph 24: WoS articles times cited 


\section{GENERAL MANAGEMENT}

Graph 25 shows a comparison between the Scopus and Web of Science samples of articles, presenting the times cited over the period from 2011 to 2020 .

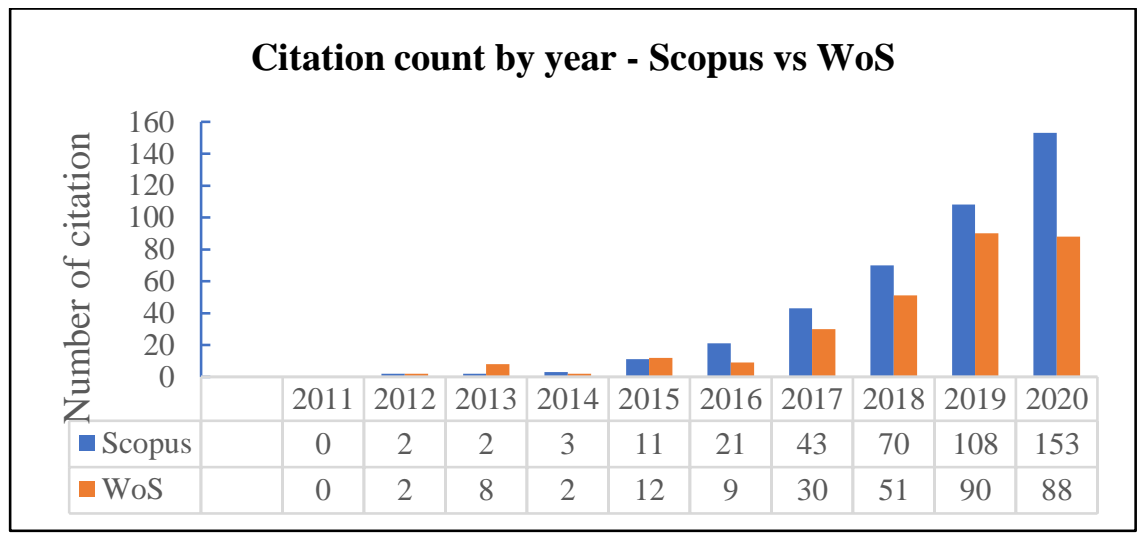

Graph 25: Citation count by year - Scopus vs WoS

\section{Field-Weighted Citation Impact}

Elsevier's Field-Weighted Citation Impact $(\mathrm{FWCl})$ is the ratio of the total citations actually received by the denominator's output, and the total citations that would be expected based on the average of the subject field. A Field-Weighted Citation Impact $<1$ means that the output is cited less than expected according to the global average and $>1$ means that the output is more cited than expected according to the global average. For example, 1.48 means $48 \%$ more cited than expected.

For the Scopus articles ( $n=104), 61$ documents present this metric, which correspond to $58.7 \%$ of the sample. The average Field-Weighted Citation Impact was 0.97 , in an interval from 0.08 to 6.02 . Graph 26 presents the $\mathrm{FWCl}$ distribution of the 61 articles. We can note that most of the scores are concentrated below the average quartile line.

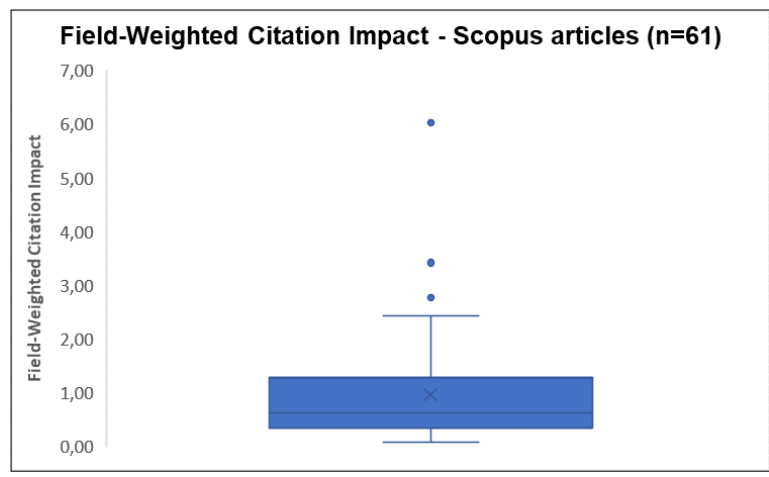

Graph 26: Field-Weighted Citation Impact - Scopus

\section{H-Index}

The Hirsch's $h$-index is defined as the maximum value of $h$ such that the given author/journal has published $h$ papers that have each been cited at least $h$ times. The index is designed to improve upon simpler measures such as the total number of citations or publications. The average $\mathrm{H}$-index of WoS analysed articles was 8. The Scopus database does not present the average of this index in a research citation report.

\subsection{Keywords}

In the sample of non-duplicate articles from the WoS and Scopus databases $(n=170)$, a total of 811 author keywords were found, of which 580 are distinct from each other. Then a clustering of keywords with the same meaning was applied (e.g., cohesion funds = cohesion fund, EU funds = European funds), which resulted in 525 different words. Table 3 shows the 45 most frequently grouped keywords, which appear at least 3 times.

\begin{tabular}{|l|l|}
\hline Most frequent keywords (> 3 occurrences) & Occurrences \\
\hline $\begin{array}{l}\text { European fund(s)/EU funding/EU funds/European Union Funds/The European } \\
\text { funds/Funding/Funds }\end{array}$ & 55 \\
\hline $\begin{array}{l}\text { ESIF/EU structural and investment funds/European structural and investment funds/Structural } \\
\text { funds }\end{array}$ & 24 \\
\hline Cohesion policy/Cohesion policy of the European Union/EU Cohesion policy & 22 \\
\hline Regional development/Development regions & 16 \\
\hline
\end{tabular}




\section{GENERAL MANAGEMENT}

\begin{tabular}{|l|l|}
\hline Sustainable development & 13 \\
\hline EU/European Union/The European Union/The EU & 12 \\
\hline Investment(s) & 7 \\
\hline Romania & 7 \\
\hline Rural development & 7 \\
\hline EU regional policy/European regional policy/Regional policy & 6 \\
\hline Agriculture & 5 \\
\hline Efficiency & 5 \\
\hline Smart specialisation & 5 \\
\hline Absorption rate & 4 \\
\hline Cohesion Fund(s) & 4 \\
\hline Convergence & 4 \\
\hline Development & 4 \\
\hline ERDF/European Regional Development Fund & 4 \\
\hline Evolution & 4 \\
\hline Extremadura & 4 \\
\hline Geographic(al) information system(s)/GIS & 4 \\
\hline Operational program(s) & 4 \\
\hline Absorption & 3 \\
\hline Absorption capacity & 3 \\
\hline Absorption of EU funds/European funds absorption & 3 \\
\hline CAP/Common agricultural policy & 3 \\
\hline Central and Eastern Europe & 3 \\
\hline Cross-border collaboration/Cross-border cooperation (CBC) & 3 \\
\hline Economic(al) development & 3 \\
\hline Economic growth & 3 \\
\hline Europe 2020/Europe 2020 strategy & 3 \\
\hline European financial support/European financing/European support funds & 3 \\
\hline Herfindahl-Hirschman index/The Herfindahl-Hirschman index & 3 \\
\hline LEADER method/Leader method (2007-2013) & 3 \\
\hline National Rural Development Programme 2007-2013/NRDP (Romania) & 3 \\
\hline Poland & 3 \\
\hline Principal component analysis & 3 \\
\hline Project(s) & 3 \\
\hline Regional economy/Regional economics & 3 \\
\hline Regionalisation & 3 \\
\hline Risk(s)/@Risk & 3 \\
\hline Rural area(s) & 3 \\
\hline SMEs (Small and medium-sized enterprises) & 3 \\
\hline Social accounting matrix(ces) & 3 \\
\hline Strategy(ies) & 3 \\
\hline & \\
\hline
\end{tabular}

Table 3: Most frequent keywords

In order to illustrate the most used keywords by the authors, word clouds were created using the software called MAXQDA Analytics Pro. Figure 2 presents the cloud of one keyword, and
Figure 3 displays the cloud of two keywords. The keywords that appear at least 3 times were considered.

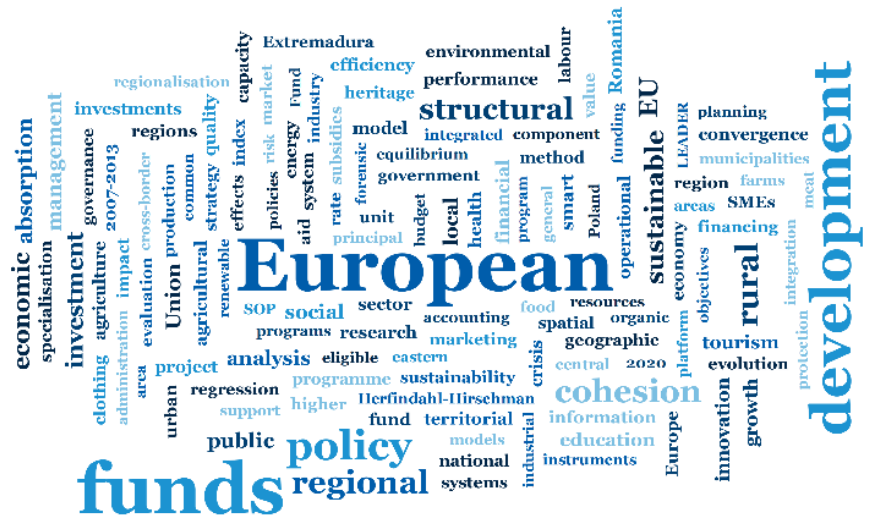

Figure 2: One keyword cloud (Scopus and WoS data) 


\section{GENERAL MANAGEMENT}

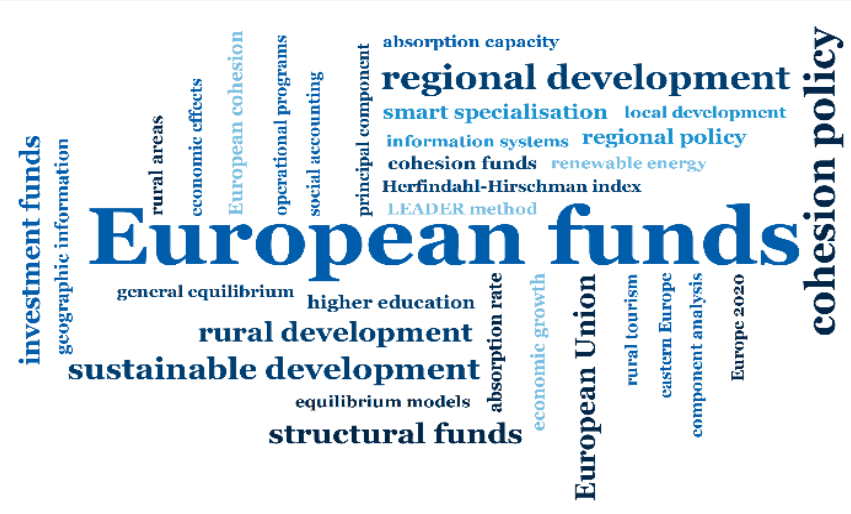

Figure 3: Two keyword cloud (Scopus and WoS data)

\subsection{Research agenda and trends}

The identification of the study themes and publication trends was instrumentalized by reading the abstracts of the 170 non- duplicated articles, in a more qualitative approach. Table 4 summarizes the research agenda addressed by the studies, over the period 2011-2020.

\begin{tabular}{|c|c|c|}
\hline Year & Empirical application & Themes of research \\
\hline 2011 & Romania (7); Croacia (1) & $\begin{array}{l}\text { Trends of investments in post-crisis period; environmental protection; Common } \\
\text { Agriculture Policy (CAP); rural development; competitiveness and entrepreneurial } \\
\text { initiatives for young people; internal audit in public institutions; absorption of EU } \\
\text { funds; sustainable development (SD); EU budget and financial burden distribution } \\
\text { principle; local communities' development; regional development (RD); use of } \\
\text { renewable energy. }\end{array}$ \\
\hline 2012 & $\begin{array}{l}\text { Romania (5), BELL (1); } \\
\text { CEE (1); Turkey (1) }\end{array}$ & $\begin{array}{l}\text { Impacts of ESIF in world economic crisis; sustainable development; absorption of } \\
\text { EU funds; ESF funds for human resources development; beneficiary's } \\
\text { satisfaction; Performance of banking institutions by supporting EU funds; rural } \\
\text { development; EU efficiency to support economic growth; Regional Development } \\
\text { Agencies; agricultural exploitation. }\end{array}$ \\
\hline 2013 & $\begin{array}{l}\text { Romania (4); Italy (1); } \\
\text { Portugal (1); Latvia (1); } \\
\text { EU (1) }\end{array}$ & $\begin{array}{l}\text { Cross-compliance requirements (audit); CAP; enhancing level of education and } \\
\text { access to the regional labour market; legal aspects for RD; inequality and } \\
\text { economic growth; SD of higher education and research; absorption rate of EU } \\
\text { funds; knowledge platform for the water technology sector; rural development; } \\
\text { territorial division and cultural identity. }\end{array}$ \\
\hline 2014 & $\begin{array}{l}\text { Romania (9); EU (2); CEE } \\
\text { (1); Poland (1); } \\
\text { Slovak Republic (1), } \\
\text { Czech Republic and } \\
\text { Hungary (1); Spain (1); } 7 \\
\text { European border regions } \\
\text { (1) }\end{array}$ & $\begin{array}{l}\text { Recovery of economic differences between West and East Europe; Pan-European } \\
\text { Transport Corridors; Cross-border health care collaboration (hospitals); } \\
\text { agriculture, fisheries and regional specialisation; funding for Civil Society } \\
\text { Organizations (CSO) and associative democracy; smart specialisation for } \\
\text { research and innovation (RIS3); investments in an airport; integration of disabled } \\
\text { people on the labour market; RD and economic cohesion reinforcement; } \\
\text { agricultural and rural development, CAP; funds management; consumption of } \\
\text { non-renewable resources; SD; labour productivity and employees indicators; } \\
\text { absorption of EU funds (fiscal capacity and local administration); impact of } \\
\text { Programme for Rural Development (SAPARD) on the tourism supply; restoration } \\
\text { of historical heritage; strategic decision making for RD; ESIF impacts in the } \\
\text { employment. }\end{array}$ \\
\hline 2015 & $\begin{array}{l}\text { Romania (7); Italy (2); } \\
\text { Spain (2); Europe (1); } 7 \\
\text { European border regions } \\
\text { (1) }\end{array}$ & $\begin{array}{l}\text { Cross-border health care collaboration (hospitals); Marketing-mix of financed } \\
\text { projects; LEADER method; changes in rural landscapes; CAP; rural development } \\
\text { (sectors of organic farming, freshwater aquaculture and poultry meat); knowledge } \\
\text { platform for sustainable rural development; credit to agriculture; influence of the } \\
\text { corruption on the EU funds absorption; SD; websites as a marketing tool to } \\
\text { improve RD; economic impact of the withdrawal of ESIF using Computable } \\
\text { General Equilibrium Model (CGE); CGE) for analyse the impact of ESIF for the } \\
\text { regional growth. }\end{array}$ \\
\hline 2016 & $\begin{array}{l}\text { Romania (5); Poland (4); } \\
\text { Spain (2); Hungary (1); } \\
\text { Lithuania (1); UE (1) }\end{array}$ & $\begin{array}{l}\text { Solar power generation; (RIS3); renewable sources in energy production; local } \\
\text { conflicts in wind farms; development of forensic medicine; ERDF for the tourism } \\
\text { economy; impacts of EU funds in the rural labour market (HR development and } \\
\text { employment); RD and growth; economic SD after Brexit; cohesion policy for } \\
\text { diminishing external migration; waste sector and rehabilitation of contaminated } \\
\text { sites; rural tourism; geographic information platforms; LEADER method. }\end{array}$ \\
\hline
\end{tabular}




\begin{tabular}{|c|c|c|}
\hline 2017 & $\begin{array}{l}\text { Romania (8); Poland (5); } \\
\text { Spain (4); EU (3); Italy (2); } \\
\text { Hungary (1); Greece (1); } \\
\text { France and Spain (1); UK } \\
\text { (1); Slovenia (1); Poland } \\
\text { and Ukraine (1) }\end{array}$ & $\begin{array}{l}\text { Challenges in cohesion policy after 2020; SD strategy in the energy sector; } \\
\text { development of health equity; Europeanization of CEO due to economic crisis; } \\
\text { integrated territorial investment for local urban development; impacts of transition } \\
\text { on agriculture and rural areas; impact of institutional quality on regional economic } \\
\text { growth; rural sustainability of the meat (parma ham DPO); cohesion policy and } \\
\text { RD; public space transformation at regional level; investments to agritourism } \\
\text { farms due to infrastructure modernization; changes in the landscape of rural } \\
\text { villages; economic development; rural development (blueberries crop, SAPARD); } \\
\text { agri-environment; EU funds absorption; projects for healthcare education, in } \\
\text { perspective of user satisfaction; SD with organic agriculture; impact of non- } \\
\text { reimbursable funds for social economy; education in rural areas during the crisis; } \\
\text { development of educational sector; effects of austerity in institutional change, work } \\
\text { organization and employment relations; revitalization of cultural heritage; CF } \\
\text { funding of cultural projects; LEADER Method; sustainable forest management due } \\
\text { to climate-change; impacts on the cohesion policy after Brexit. }\end{array}$ \\
\hline 2018 & $\begin{array}{l}\text { Romania (6); Poland (4); } \\
\text { Spain (4); EU (3); } \\
\text { Portugal (2); Czech } \\
\text { Republic (2); Portugal } \\
\text { and Spain (1); South } \\
\text { Europe (1), Russia (1), } \\
\text { CEE (1); Germany and } \\
\text { The Netherlands (1); } \\
\text { Eurozone (1); } 7 \text { cities in } \\
\text { Britain, Ireland, France, } \\
\text { Germany, Spain and Italy } \\
\text { (1) }\end{array}$ & $\begin{array}{l}\text { Urban infrastructure of old industrial cities and effects of climate changes; } \\
\text { administrative capacity of institutions for ESIF absorption; improvement of PA } \\
\text { quality with ESIF (reform after 2000); financing of corporate social responsibility } \\
\text { activities in sugar-producing; social cohesion in EU urban areas, at local level; } \\
\text { efficiency of EU funds to RD considering the transport sector; spatial analysis of } \\
\text { EU funds effectiveness on regional growth; RD administration - role of } \\
\text { municipalities; spill-over effects of } 2013 \text { structural funds reform (crises } \\
\text { management); human SD within engineering studies; management system for a } \\
\text { stable regional growth; preferences of residents on the ESIF allocation for RD; the } \\
\text { reform of } 2013 \text { into the EU cohesion policy and implications on macroeconomics } \\
\text { indicators; international financial transfers for economic development; municipal } \\
\text { sustainability influence in fostering economic and social development; effect of the } \\
\text { ESIF on overall local authority performance; evaluation of smart cities strategies } \\
\text { for a smart growth and competitiveness; results of an agro-food programme; risk } \\
\text { management as a method to improve the absorption of EU funds; rural } \\
\text { development with financing of subsistence farms; seismic protection measures to } \\
\text { preserve heritage buildings; absorption of ESIF for agriculture and forestry } \\
\text { products; analysis of regional innovation strategies of Russia with RIS3; funding } \\
\text { for ecological tourism, with a sustainable environmental management; impacts of } \\
\text { ERDF funds for RD (R\&D, ICT, SMEs); impact of FEDER on the growth and } \\
\text { employment; ESIF impacts on SD and urban environment; impact of the reform of } \\
\text { the cohesion policy in post-2020 horizon. }\end{array}$ \\
\hline 2019 & $\begin{array}{l}\text { Romania (10); EU (3); } \\
\text { Portugal (2); Poland (2); } \\
\text { Italy (2); Slovak Republic } \\
\text { (1); Czech Republic (1); } \\
\text { CEE (1); Bulgaria (1); EU- } \\
15 \text { (1); } 11 \text { EU north and } \\
\text { western countries (1) }\end{array}$ & $\begin{array}{l}\text { EU fund selectivity skill and profitability; income convergence effects of EU funds } \\
\text { in spatial spill-overs; environmental development of municipalities; influence of the } \\
\text { cohesion policy and spatial analysis on regional growth; impact of ESIF on } \\
\text { economic growth; influence of cohesion policy for the EU image on the citizens } \\
\text { view; RIS3 on Energy (hydrogen technologies H2020); impact of ERDF on new } \\
\text { firms formation (SMEs); SD with healthy tourism ( "age-friendly"); circular } \\
\text { economy in the construction sector; SD of urban areas: Jessica initiative } \\
\text { (ecosystem services); governance and innovation on rural territory for RD; impact } \\
\text { of H2020 programme on RD; cohesion policy and RD; social services for elderly } \\
\text { people; developing the social economy and HR for the metallurgical industry; } \\
\text { econometric model for analysing the economic and social development; public } \\
\text { private partnerships to accelerate the absorption of EU funds; rural development: } \\
\text { investments for meat processing industry; absorption effects of EU funds for the } \\
\text { competitiveness of SMEs; EU funds for historical monuments and cultural } \\
\text { heritage; storage capacities of field crops production; SAPARD and } \\
\text { competitiveness of fruit farms; impacts of public procurement in tertiary education } \\
\text { sector. }\end{array}$ \\
\hline 2020 & $\begin{array}{l}\text { Romania (9); Poland (3); } \\
\text { Bulgaria (2); Poland and } \\
\text { Romania (1); Bulgaria } \\
\text { and Romania (1); } \\
\text { Portugal and Spain (1); } \\
\text { Scotland-UK (1); Slovak } \\
\text { Republic (1); UE (1); CEE } \\
\text { (1) }\end{array}$ & $\begin{array}{l}\text { EU funds for higher education institutions; big projects and development of } \\
\text { municipalities; impact of ESIF for CEE socioeconomic development; efficiency } \\
\text { and economic performance of EU funds for agriculture; development of digital } \\
\text { rural hubs; RIS3 projects; RIS3 for competitiveness of SMEs in the textile and } \\
\text { clothing sector; results of SMEs investments for innovation and competitiveness; } \\
\text { development of transational industrial policies (SMEs); cross-border cooperation } \\
\text { of eurocities; audit analysis and absorption of EU funds; CAP evolution and } \\
\text { absorption rate; impact of EU funds on rural development and rural } \\
\text { entrepreneurship; EU funds for research, development and innovation (FP7 and } \\
\text { H2020 programmes); cohesion policy and territorial distribution of financing; SD } \\
\text { strategies for rural areas; promotion of gender equality and mainstreaming; long } \\
\text { term planning for Partnership Agreement on social development. }\end{array}$ \\
\hline
\end{tabular}

Table 4: Themes of research and trends 


\section{Final Considerations}

The mapping of bibliometric data of this study, collected from two of the world's leading scientific databases, is relevant for scholars analysing the impacts of European funds on the development and economic growth of EU members and the Cohesion Policy. From the data analysis, reported in the previous section, some considerations are allowed. First, referring to the year of publication of the articles, although the sample of 170 articles points to a slight decrease in articles from 2017, in 2020 there was an increase in publications in the WoS, while in Scopus there was a sharp drop from 2019 to 2020. There may be a connection to the Coronavirus pandemic context experienced in 2020. However, we highlight the fact that a large number of the articles indexed in WoS in 2020 were published in a single journal.

As for the authorship of the articles, there is a prevalence of Romanian authors at the top of the ranking of publications in both databases. The same trend can be observed for the journals with the highest number of publications (from Romania). As regards the countries that published the most articles, there is a concentration of institutions of affiliation in Central and Eastern European countries (the leader is Romania, followed by Poland), and then Southern European countries (Spain, Portugal, and Italy). However, there is some cooperation with other countries, namely the Netherlands, the United Kingdom and Belgium.

When looking at where the empirical studies were conducted, however, the concentration of production in CEE countries becomes even more visible. It corresponds to $66 \%$ of the studies, followed by the Southern European countries $(18 \%$ of the studies).

Considering that CEE countries joined the European Union more recently, in the 2000 s, and that they are more vulnerable economies in the European scenario, alongside the southern countries, it is plausible that the scientific interest of researchers reflects the applicability of European cohesion policy investments. It should also be remembered that the CEE countries were under the domination of the Soviet Union and the socialist regime for over 40 years and that after the collapse of the Warsaw Pact, the economies had to undergo a process of transition to a market economy, territorial decentralisation and democratisation. It is assumed that European aid had a key impact on this process from earlier on, when they received preaccession funds. The studies from Romania particularly show a central concern with the absorption rate of EU funds, a concern which is transversal to the different domains and territorial coverage of the studies analysed herein.

Another result to highlight is that Scopus presented a much wider coverage of open access than Web of Science, although it cannot be assumed that the results found here apply to the majority of publications indexed in these databases.

In the analysis of data on impact factors, which is very important in a bibliometric study, it is noted that almost half of the articles analysed were never cited. There were rare articles that were cited many times, and they appear as outliers in the statistical analyses. However, an increasing trend was observed in the number of citations over the years, especially in 2020.

Regarding the subject and knowledge areas of the studies, most articles focus on the areas of Social Sciences, Economics, Management and Environmental Sciences. The main research topics include the impact of European funds on regional development and socio-economic growth, EU cohesion policy and its spin-offs, the use of smart specialisation platforms for innovation, development and research (RIS3), institutional capacity to absorb EU funds, rural and sustainable development in a variety of approaches (linked to the Common Agricultural Policy, spatial urbanisation, and some more innovative such as rural tourism). From 2017, a theme that has gained more interest is the incentives given to foster the competitiveness and innovation of SMEs (which is compatible with the Europe 2020 strategy).

Other current and innovative topics addressed are the investments to tackle climate change, social and economic repercussions after Brexit, the use of knowledge platforms, the image of the European Union from the citizens' point of view, the circular economy, cross-border cooperation, the preservation of cultural heritage, health initiatives, social policy for elderly people, gender equality, employment and the labour market, and the impacts of the economic crisis on EU funding.

This study has some limitations. Firstly, the literature searched was retrieved from journals indexed only in the Scopus and Web of Science databases, and publications indexed in other databases were not analysed. Secondly, the terms defined for the research were limited to European funds, economic growth, development and economic impacts, and possible synonyms for these terms were neglected in the search, such as "subsidies", "aid", "funding", just to name a few. Thirdly, the choice of the term development for the search of articles may have created a bias with the term "sustainable development", which can be observed by the expressive amount of articles found on this topic. Another limitation of the study is that the search was restricted to the English language, which may certainly have left out other relevant documents.

As this study unfolds, there are many opportunities for future research. The study did not analyse the occurrence of networks and co-authorship relations, which can be addressed in other studies. In addition, research in other databases, such as Google Scholar, could enrich this work, with a single or comparative analysis. Furthermore, this study has restricted the criteria search to scientific journal articles. It would be certainly interesting to know what has been published on the subject in scientific conferences and other types of publication, such as books and book chapters. Bibliometric analysis is a vast science, which allows the use of different tools and a variety of developments.

\section{References}

[1] Araújo, C. A. A. (2006). Bibliometria: evolução histórica e questões atuais. Em questão, 12(1), 11-32.

[2] Bähr, C. (2008). How does Sub-National Autonomy Affect the Effectiveness of Structural Funds? Kyklos, 61(1), 3-18. doi:10.1111/j.1467-6435.2008.00389.x

[3] Becker, S. O., Egger, P. H., \& von Ehrlich, M. (2018). Effects of EU Regional Policy: 1989-2013. Regional Science and Urban Economics, 69, 143-152. doi:10.1016/j.regsciurbeco.2017.12.001

[4] BEUGELSDIJK, M., \& EIJFFINGER, S. C. W. (2005). The Effectiveness of Structural Policy in the European Union: An Empirical Analysis for the EU-15 in 1995-2001*. JCMS: Journal of Common Market Studies, 43(1), 37-51. doi:10.1111/j.00219886.2005.00545.x

[5] Michele Boldrin, Fabio Canova, Inequality and convergence in Europe's regions: reconsidering European regional policies, Economic Policy, Volume 16, Issue 32, 1 April 2001, Pages 206253, doi: 10.1111/1468-0327.00074

[6] Cappelen, A., Castellacci, F., Fagerberg, J., \& Verspagen, B. (2003). The Impact of EU Regional Support on Growth and Convergence in the European Union. JCMS: Journal of Common Market Studies, 41(4), 621-644. doi:10.1111/1468-5965.00438

[7] Checherita, C., Nickel, C., Rother, P. (2009). The role of fiscal transfer for regional economic convergence in Europe. European Central Bank, Working Paper Series, 1029.

[8] Costa, T., Fernández-Limós, F. S. L., Amante, M. J, Lopes, P. F. (2012). A Bibliometria e a avaliação da produção científica: indicadores e ferramentas.

[9] Crescenzi, R., Giua, M. (2014). The EU cohesion policy in context: regional growth and the Influence of agricultural and rural development policies. London School of Economics, LEQS Paper, 85 (2014). 


\section{GENERAL MANAGEMENT}

[10] Dall'erba, S. (2005). Distribution of regional income and regional funds in Europe 1989-1999: An exploratory spatial data analysis. The Annals of Regional Science, 39(1), 121-148. doi:10.1007/s00168-004-0199-4.

[11] Dall'erba, S., \& Le Gallo, J. (2008). Regional convergence and the impact of European structural funds over 1989-1999: A spatial econometric analysis*. Papers in Regional Science, 87(2), 219244. doi:10.1111/j.1435-5957.2008.00184.x

[12] Dall'erba, S., Guillain, R., Le Gallo, J. (2009). Impact of structura funds on regional growth: How to reconsider a 9 year-old blackbox. Région et Développement, 30, 77-99.

[13] De la Fuente, A., Vives, X., Dolado, J. J., \& Faini, R. (1995). Infrastructure and Education as Instruments of Regional Policy: Evidence from Spain. Economic Policy, 10(20), 11. doi:10.2307/1344537

[14] Dedola, L., Georgiadis, G., Gräb, J., \& Mehl, A. (2021). Does a big bazooka matter? Quantitative easing policies and exchange rates. Journal of Monetary Economics, 117, 489-506. doi:10.1016/j.jmoneco.2020.03.002

[15] Ederveen, S., Gorter, J., de Mooij, R., Nahuis, R. (2003). Funds and games: the economics of European cohesion policy. European Network of Economic Policy Research Institutes, Occasional Paper 3 (2003).

[16] Ederveen, S., Groot, H. L. F., \& Nahuis, R. (2006). Fertile Soil for Structural Funds?A Panel Data Analysis of the Conditional Effectiveness of European Cohesion Policy. Kyklos, 59(1), 17-42. doi:10.1111/j.1467-6435.2006.00318.x

[17] Esposti, R., \& Bussoletti, S. (2008). Impact of Objective 1 Funds on Regional Growth Convergence in the European Union: A Paneldata Approach. Regional Studies, 42(2), 159-173. doi:10.1080/00343400601142753

[18] European Commission (2017). My Region, My Europe, Our Future: Seventh Report on Economic, Social and Territorial Cohesion Publications Office of the European Union. Availaible at http://ec.europa.eu/regional_policy/en/information/cohesion-report

[19] European Commission Data (2021). European Structural and Investment Funds: EU Overview. Available at https://cohesiondata.ec.europa.eu/overview

[20] EUR-Lex (1957). Treaty establishing the European Community (Amsterdam consolidated version). European Union Law, available at https://eurlex.europa.eu/legalcontent/EN/TXT/?qid=1551626284016\&uri=CE LEX:11997E

[21] Faculdade de Ciências da Universidade de Lisboa. (2021). Ferramentas Bibliométricas. Available at https://ciencias.ulisboa.pt/pt/ferramentas-bibliom\%C3\%A9tricas
[22] Fiaschi, D., Lavezzi, A. M., Parenti, A. (2011). Productivity growth across European regions: the impact of structural and cohesion funds. University of Pisa, Discussion Paper 84.

[23] Gagliardi, L., \& Percoco, M. (2016). The impact of European Cohesion Policy in urban and rural regions. Regional Studies, 51(6), 857-868. doi:10.1080/00343404.2016.1179384

[24] Garcia-Milà, T., \& McGuire, T. J. (2001). International Tax and Public Finance, 8(3), 281-296. doi:10.1023/a:1011264107134

[25] Malakhova, T. S., Kapustin, P. P., Morusov, S. A., \& Udovik, E. E. (2020). European Practice in Ensuring Sustainable Development: Problems and Contradictions. International Journal of Economics and Business Administration, VIII(Special Issue 1), 14-23. doi:10.35808/ijeba/499

[26] Maynou, L., Saez, M., Kyriacou, A., \& Bacaria, J. (2014). The Impact of Structural and Cohesion Funds on Eurozone Convergence, 1990-2010. Regional Studies, 50(7), 1127-1139. doi:10.1080/00343404.2014.965137

[27] Mohl, P., Hagen, T. (2008). Which is the right dose of EU cohesion policy for economic growth? ZEW - Centre for European Economic Research, Discussion Paper 8 (104).

[28] Mohl, P., \& Hagen, T. (2010). Do EU structural funds promote regional growth? New evidence from various panel data approaches. Regional Science and Urban Economics, 40(5), 353365. doi:10.1016/j.regsciurbeco.2010.03.005

[29] OECD (2020). Meeting of the OECD Council at Ministerial Level 2020. Key issues paper, pp. 1-60.

[30] Okubo, Y. (1997). Bibliometric indicators and analysis of research systems: methods and examples. Paris, OECD.

[31] Pritchard, A. (1969). Statistical bibliography or bibliometrics? Journal of Documentation, 25(4), 348-349.

[32] Puigcerver-Peñalver, M. C. (2007). The Impact of structural funds policy on European regions' growth: a theoretical and empirical approach. European Journal of Comparative Economics, 4(2), 179208.

[33] Rodríguez-Pose*, A., \& Fratesit, U. (2004). Between Development and Social Policies: The Impact of European Structural Funds in Objective 1 Regions. Regional Studies, 38(1), 97-113. doi:10.1080/00343400310001632226

[34] Sala-i-Martin, X. X. (1996). Regional cohesion: evidence and theories of regional growth and convergence. European Economic Review, 40(6), 1325-1352. doi:10.1016/0014-2921(95)00029-1

[35] Zupic, I., \& Čater, T. (2014). Bibliometric Methods in Management and Organization. Organizational Research Methods, 18(3), 429472. doi:10.1177/1094428114562629 